Research Letter

\title{
International Committee of the Red Cross: supporting, protecting, and providing medical care to Russian emigrants in the 1920s-1930s
}

\author{
Lyudmila V. Klimovich ${ }^{1}$, Valery V. Suvorov ${ }^{2}$, Leonid A. Shaipak ${ }^{1}$ \\ ${ }^{1}$ Ulyanov State Pedagogical University, Ulyanovsk, Russia \\ ${ }^{2}$ Saratov State Medical University, Saratov, Russia
}

Received 15 April 2020, Revised 2 May 2020, Accepted 23 May 2020

(C) 2020, Klimovich L.V., Suvorov V.V., Shaipak L.A.

(C) 2020, Russian Open Medical Journal

Abstract: The Russian Red Cross Society was abolished in Soviet Russia in January 1918, but the Soviet Red Cross was created only in 1923. Part of the Russian Red Cross Society (RRCS) staff was able to emigrate and continue its activities abroad, aimed at helping and supporting Russian emigration. The article investigates the role of the RRCS in emigration; analyzes the number of people who had received assistance, including medical aid; and states, in which European countries the RRCS was most active.

The chapters of the International Red Cross rendered prodigious assistance to the Russian emigration: in particular, the American Red Cross financed a sanitarium for emigrants with tuberculosis, and provided assistance to an orphanage in Czechoslovakia. The Czechoslovak Red Cross, both directly and through the structures of the so-called Committee of Zemstvos and Towns for Assistance to Russian Citizens Abroad (Zemgor), participated in supporting emigration: it financed the stay of students in sanitariums and hospitals, and allocated funds for the functioning of the division of medical assistance at the Zemgor. Despite the fact that the Czechoslovak Red Cross was formed just in 1919, on account of the active actions of its chairman, Alice Masaryk (the daughter of the Czechoslovak President), it was able to attract financial resources and organize assistance to people, including Russian emigrants.

Keywords: Russian Red Cross Society, International Committee of the Red Cross, American Red Cross, Czechoslovak Red Cross, Russian emigration, social and medical support.

Cite as Klimovich LV, Suvorov VV, Shaipak LA. International Committee of the Red Cross: supporting, protecting, and providing medical care to Russian emigrants in the 1920s-1930s. Russian Open Medical Journal 2020; 9: e0420.

Correspondence to Lyudmila V. Klimovich. E-mail: lusek84@yandex.ru.

\section{Introduction}

Protecting human life and health is a priority task of modern society. Its fulfilment is to a large extent ensured owing to the activities of the International Red Cross and Red Crescent Movement - a global humanitarian network, operating in over 170 countries and comprising of the National Red Cross and Red Crescent Societies [1]. The movement includes the International Committee of the Red Cross (ICRC), founded in 1863, when twelve countries signed the Geneva Convention, an international agreement for the improvement of the situation with wounded and sick in the armies. The agreement proclaimed the principles of independence of hospitals and medical personnel, and assistance to the wounded combatants [2]. Over time, national branches of the Red Cross began to emerge [3]. One of the most important issues on the ICRC agenda is the problem of migration and refugees [4], which was explicitly manifested in the 1920s in connection with the mass emigration from the Soviet Russia.

The Russian Society for the Care of Wounded and Sick Warriors, established in 1867, immediately joined the Geneva Convention [5, p. 10], and in 1879 it was renamed the Russian Red Cross Society (RRCS). The RRCS trained unlicensed assistive personnel for wartime, organized the collection of donations, opened hospitals, and provided financial assistance to those in need [6]. The revolutionary events of 1917 , as well as the coming to power of the Bolsheviks, made adjustments to the further RRCS activities. In January 1918, the Council of People's Commissars of the Russian Soviet Federative Socialist Republic (CPC RSFSR) adopted a decree on the transfer of property and capital of the institutions within the RRCS into state ownership [5, p. 21]. In July 1918 , the CPC RSFSR adopted a decree on the reorganization of RRCS, which laid the foundation for the Soviet Red Cross. It should be noted that ICRC did not recognize the newly created organization. Although they were invited to the International Conference of the Red Cross Organizations in the spring of 1921, they refused to come. The conference was attended by the representatives of the pre-revolutionary RRCS, surviving in emigration [5, p. 38].

In the fall of 1921, the ICRC recognized the Soviet Red Cross, but at the same time it was emphasized, 'that such recognition does not mean that the ICRC is abandoning the actual ties it maintained with the former Russian Red Cross organization, given the humanitarian activities that it carried out and continues to carry out outside the territory of the Soviet Republic, providing assistance to Russian refugees abroad' [5, p. 40]. Thus, two 
organizations began to exist that represented the interests of former subjects of the Russian Empire in the ICRC.

The management of the former RRCS moved its activities initially to the south of Russia and Siberia, and then abroad. In February 1921, the General Directorate of the Russian Red Cross Society in Paris was established under the chairmanship of P.N. Ignatiev, B.E. Ivanitsky and B.E. Nolde. After the recognition of the Soviet Red Cross by the ICRC, the society began to bear the name of the General Directorate of the Former Institution of the Russian Red Cross Society, as was reported to the ICRC in March 1923 [5, p. 44]. At first, the activities of the organization were supported by local governments, but with time, the number of appropriations declined against the general background of a worsening economic and international situation, which resulted in the closure of a number of RRCS institutions. It is worth noting the fact that, during the World War I, the RRCS offices worked in different countries, and many simply did not have time to return to Russia, continuing their activities abroad, aiming to help and support their compatriots [7, p. 72].

After the revolutionary events of 1917 in Russia and the Civil War, there were many people in emigration from Russia who were unable to live independently in a foreign country; among them, there were children, the elderly, and the disabled. The experience of charity and social assistance, which was traditional for prerevolutionary Russia, was revived in emigration. A crucial role in this was played by the General Directorate of the Former Organization of the Russian Red Cross Society. The main attention of the RRCS was paid to the disabled, children and the elderly. Over 1921-1925, the RRCS spent 24 million francs (about $15,000,000$ dollars) [7, p. 72]. The RRCS was funded by the ICRC, national governments, through charitable giving by the emigrants themselves. It is important to note that the ICRC recognized the RRCS as a representative of the Russian emigration, which allowed the ICRC to finance it. Prior to the World War II, in 1937, the RRCS received a large donation of about $\$ 15,000$ from the American Society for the Relief of Russian Exiles [7, p. 72].

In the 1920s, the RRCS managed to open medical institutions that were in high demand by the refugees from Russia. For example, in the Kingdom of Serbs, Croats and Slovenes (Kingdom of SCS), a surgical hospital was established in Pančevo, which was headed by V.A. Levitsky [8, p. 208]. The hospital was assisted by the American Red Cross and the British Committee of the RRCS; in the late 1930s, the sanitarium began to bear the name of Russian Red Cross Sanitarium of King-Knight Alexander I the Unifier in the city of Pančevo [8, p. 208].

For tuberculosis patients, a sanitarium functioned in the Vurberk Castle, which was equipped with an X-ray room, an operating room, a laboratory [9, p. 64]. An outpatient clinic with a children's department was opened in Belgrade. Besides, there were dental offices and outpatient clinics at hospitals in a number of large cities [10, p. 110]. The opening of many medical institutions with the support by the RRCS in the cities of the Kingdom of SCS was a prodigious contribution to the arrangement of the social life of emigrants, since most of them had low incomes [11, p. 55].

A special category of Russian refugees was composed of the disabled in the World War I and the Civil War. They could not earn their living on their own and were constantly in need of medical care. In different countries, the issue of supporting Russian handicapped people was resolved in different ways: for example, in the Kingdom of SCS, a pension was established from the state treasury $[9,62]$. RRCS in the city of Igalo (Dalmatia), with the support from the government of the Kingdom of SCS, opened the Shelter of the Russian Red Cross Society for the elderly, handicapped and disabled. In 1931, the shelter was transferred to Velika Kikinda in the building of the former Grammar School for the Russian and Serbian Girls No.1. There was an outpatient clinic and an infirmary at the shelter. After the occupation of Yugoslavia, the RRCS office was liquidated [10, p. 130].

The RRCS was engaged in placing emigrant orphan children into families rather than providing medical care alone. By 1930, RRCS chapters around the world maintained three hospitals, a tuberculosis sanitarium, two nursing homes, one home for invalids, four orphanages, a canteen, four shelters and three work premises for refugees [7, p. 72].

Because of the massive nature of Russian emigration after 1917, Europe, for the first time, faced the refugee problem. In addition to the undefined legal status, there was an acute issue of their financial support and assistance with getting settled at a new place. Along with the RRCS, the ICRC and its national chapters played a vital role in this process. Working with Russian refugees, the ICRC transformed from a purely medical institution into a charitable organization with a wide range of activities.

The most fruitful assistance to the Russian emigration came from the American Red Cross Society, the Czechoslovak Red Cross, the Red Cross of the Kingdom of SCS.

The Czechoslovak chapter of the Red Cross was actively established in February 1919 under the leadership of the daughter of the President of Czechoslovakia, Alice Masaryk. The fledgling organization planned to support the sick and those in need in peacetime. The Czechoslovak Red Cross did a lot to help Russian emigrants. Representatives of the Czechoslovak Red Cross were part of the Medical Commission, which examined students from among Russian emigrants in order to issue an opinion on a possible postponement of taking examinations [12]. In the report of the Medical Commission there was information that, 'some students were in clinics, hospitals, sanitariums, referred by committee doctors through the Czechoslovak Red Cross and thereby acquired the right to academic benefits' [12]. The most common diseases among students were tuberculosis (out of 556 examined, 53\% were sick [13]), nervous and mental ailments (14\%), and gastrointestinal disorders (7\%) [12].

At the initiative of the Czechoslovak Red Cross, the Census Commission carried out a census of students among Russian emigrants in 1923. Exact number of young Russian emigrants was necessary to know in order to calculate the expanse of aid; therefore, in order to collect complete information, it was proposed, 'One of the measures to ensure the completeness of the data that has to be collected, the Commission would consider the requirements for each student, when receiving any kind of assistance, both from the Red Cross and other Czech or Russian organizations, to have a certificate of a person's participation in the census, attached to the enrollment list' [14].

The Czechoslovak Red Cross provided support to various categories of emigrants, and the youngest were not the exception. For example, in 1924, a kindergarten for children of emigrants from the city of Prague spent the summer in the village, for which it needed additional funds, and 'bed linen and blankets for this time were provided by the Czechoslovak Red Cross' [15]. 
The American Red Cross provided extensive support to refugees from Soviet Russia, not only in terms of medical assistance, but also financially supporting the emigrants. Back in 1920, when the bulk of the refugees were still in Constantinople, the American Red Cross opened a sanitarium for 100 beds for tuberculosis patients, 'medical equipment, beds, linen, medicines, utensils were obtained from the American Red Cross; it has also provided basic food for the first days of the patients' stay' [16].

Particular attention was paid to children, many of whom had become orphans. For example, in 1921, a playground, a preparatory school for 25 people, a boarding grammar school, and a free cafeteria for children were opened in Tatavla. 'Nearly all expenses for the maintenance of these institutions are paid by American organizations and the International Red Cross' [16]. Established in 1921 in Constantinople, an orphanage for one hundred people, provided with food four times a day, was financially supported in full by the International ReB Cross and American Red Cross [16]. The Constantinople grammar school for the children of Russian emigrants was opened in 1920. Later, it was moved to Czechoslovakia, and initially enrolled 620 students. Meals for children, living at the boarding school, were initially organized through the American Red Cross; later, the students were receiving just breakfasts and money for the remaining meals of the day [16].

The American Red Cross promoted the employment of emigrants; in particular, it allocated funds for the operation of a motor-tractor school in Czechoslovakia, in which emigrants could acquire the necessary profession and later obtain a job at enterprises in Czechoslovakia [16].

Hence, part of the Russian Red Cross Society was able to emigrate and continue its activities abroad, aimed at helping and supporting Russian emigration. This publication demonstrated the RRCS role in emigration; analyzed the number of people who received assistance, including medical aid; and noted, in which European countries the RRCS was most active. The chapters of the International Red Cross provided crucial assistance to the Russian emigration: in particular, the American Red Cross financed a sanitarium for emigrants with tuberculosis, and provided assistance to an orphanage in Czechoslovakia. The Czechoslovak Red Cross, both directly and through the structures of the Committee of Zemstvos and Towns for Assistance to Russian Citizens Abroad, participated in supporting emigration: it sponsored the stay of students in sanitariums and hospitals, and allocated funds, necessary for the functioning of the medical aid division at Zemgor.

\section{References}

1. Sandoz Y. The Red Cross and Peace: Realities and Limits. Journal of Peace Research 1987; 24(3): 287-296. www.jstor.org/stable/424368.

2. International Red Cross Centenary. The British Medical Journal 1963; 1(5340): 1248-249. http://www.jstor.org/stable/20380700.

3. International Committee of the Red Cross. History. https://www.icrc.org/en/who-we-are/history.

4. Spieker H. The European Red Cross and Red Crescent Societies' Focus on Migration at the Beginning of the $21^{\text {st }}$ century. Die Friedens-Warte 2002; 77(1/2); 15-21. www.jstor.org/stable/23778667.

5. Toman I. Russia and the Red Cross (1917-1945). The Red Cross in a Revolutionary State. ICRC Activities in Russia after the October Revolution of 1917. Second edition. Moscow, Russia: International Committee of the Red Cross. 2002; 104 p. Russian. https://dlib.rsl.ru/viewer/01001867739\#?page=1.
6. The Russian Red Cross. Russian national NGO. History. Russian https://www.redcross.ru/o-nas/istoriya.

7. Hassell JE. Russian Refugees in France and the United States Between the World Wars. Transactions of the American Philosophical Society 1991; 81(7): i-vii+1-96 p. www.jstor.org/stable/1006535.

8. Rozanova IE, Trefilova OA. A Russian doctor in emigration: Vladimir Aleksandrovich Levitsky (1883-1953). Medical History 2017; 4(2): $203-$ 215. Russian https://doi.org/10.17720/2409-5583.t4.2.2017.07g.

9. Zhivanovich M. Shelter of the Russian Red Cross Society for the elderly, handicapped and disabled in the city of Velika Kikinda. Yearbook of the Alexander Solzhenitsyn House of Russian Diaspora Abroad (Ezhegodnik Doma Russkogo Zarubezhya im. A. Solzhenicyna) 2017; (7): 61-88. Russian https://www.elibrary.ru/item.asp?id=35124460.

10. Zhivanovich M. Carefully Keeping Traces: Russian Emigrants in Velika Kikinda and the Nuns of the Hopovo Monastery. Moscow, Russia: VSFUral. 2016; 226 p. Russian http://www.russiangrave.ru/assets/files/kikindaserbi.pdf.

11. Klimovich LV, Kovaleva DN. A Social and Cultural Profile of the Younger Generation of the Russian Emigration in the 1920-1930s Based on the Documents of the Archive of Yugoslavia. Balkan Forum 2019; 2: 46-59. https://elibrary.ru/item.asp?id=37559987.

12. Professor D.P. Kishensky's Report on the Activities of the Medical Commission for 1926 and 1927. National Archive of the Czech Republic (Národni Archiv ČR). F. 908. Ka. 301. Russian.

13. Klimovich LV, Suvorov VV. The spread of tuberculosis in the student milieu of Russian emigrants in Czechoslovakia in the 1920s: statistics, control measures, outcomes. Russ Open Med J 2019; 8: e0414. https://doi.org/10.15275/rusomj.2019.0414.

14. Letter from the Chairman of the Census Commission at the Czechoslovak Red Cross to the Consul, Mr. Gainy, Head of the Administrative and Economic Department of the Committee for the Education of Russian Students in the Czechoslovak Republic of October 9, 1923, No. 2, Prague. National Archive of the Czech Republic (Národni Archiv ČR). F. 746. Ka. 4. Inv. 47. Russian.

15. Report on the Kindergarten and Nursery of the Russian National Union of Cities in Prague for the 1923-1924 Academic Year. National Archive of the Czech Republic (Národni Archiv ČR). F. 908. Ka. 372. Inv. 289. Russian.

16. Report on the Activities of the Committee of Zemstvos and Towns for Assistance to Russian Citizens Abroad for February 1921-April 1922. Paris 1922. National Archive of the Czech Republic (Národni Archiv ČR). F.908. Ka. 372. Inv. 289. Russian.

\section{Authors:}

Lyudmila V. Klimovich - PhD, Associate Professor, Department of History, Ulyanov State Pedagogical University, Ulyanovsk, Russia. https://orcid.org/0000-0003-3541-7159.

Valery V. Suvorov - PhD, Researcher, Museum of History, Saratov State Medical University, Saratov, Russia. https://orcid.org/0000-0002-4181$\underline{9034}$.

Leonid A. Shaipak - DSc, Professor, Chair of the Department of History, Ulyanovsk State Pedagogical University, Ulyanovsk, Russia. https://orcid.org/0000-0002-1114-2579. 